\title{
Tumour suppressors miR-I and miR-133a target the oncogenic function of purine nucleoside phosphorylase (PNP)
} in prostate cancer

\section{S Kojima ${ }^{1,5}$, T Chiyomaru ${ }^{2,5}, K_{\text {Kawakami }}{ }^{2}$, H Yoshino ${ }^{2}$, H Enokida ${ }^{2}$, N Nohata ${ }^{3}$, M Fuse ${ }^{3}$, T Ichikawa ${ }^{4}$, Y Naya', M Nakagawa ${ }^{2}$ and $\mathbf{N}$ Seki $^{*}, 3$}

'Department of Urology, Teikyo University Chiba Medical Center, 3426-3 Anesaki, Ichihara, Chiba 299-0I I I, Japan; ${ }^{2}$ Department of Urology, Graduate School of Medical and Dental Sciences, Kagoshima University, 8-35-I Sakuragaoka, Kagoshima 890-8520, Japan; ${ }^{3}$ Department of Functional Genomics, Chiba University Graduate School of Medicine, I-8-I Inohana, Chuo-ku, Chiba 260-8670, Japan; ${ }^{4}$ Department of Urology, Chiba University Graduate School of Medicine, I-8-I Inohana, Chuo-ku, Chiba 260-8670, Japan

BACKGROUND: Our recent analyses of miRNA expression signatures showed that miR-I and miR- 133 a were significantly reduced in several types of cancer. Interestingly, miR-I and miR-I33a are located on the same chromosomal locus in the human genome. We examined the functional significance of miR-I and miR-I33a in prostate cancer (PCa) cells and identified the novel molecular targets regulated by both miR-I and miR-I33a.

METHODS and RESULTS: The expression levels of miR- I and miR- I 33a were significantly downregulated in PCa compared with non-PCa tissues. Restoration of miR-I or miR-133a in PC3 and DUI45 cells revealed significant inhibition of proliferation, migration, and invasion. Molecular target identification by genome-wide gene expression analysis and luciferase reporter assay showed that purine nucleoside phosphorylase (PNP) was directly regulated by both miRNAs. Silencing of the PNP gene inhibited proliferation, migration, and invasion in both PC3 and DUI45 cells. Immunohistochemistry detected positive staining of PNP in PCa specimens. CONCLUSIONS: Downregulation of miR-I and miR-I33a was a frequent event in PCa and both function as tumour suppressors. The PNP is a novel target gene of both miRNAs and potentially functions as an oncogene. Therefore, identification of novel molecular networks regulated by miRNAs may provide new insights into the underlying causes of PCa oncogenesis.

British Journal of Cancer (2012) I 06, 405-4I3. doi:I0.1038/bjc.201 I.462 www.bjcancer.com

Published online 8 November 2011

(c) 2012 Cancer Research UK

Keywords: microRNAs; prostate cancer; miR-I and miR-I33a; tumour suppressor; purine nucleoside phosphorylase (PNP)

Prostate cancer (PCa) is the most frequently diagnosed cancer and second leading cause of cancer deaths among men in developed countries (Cooperberg et al, 2009). In early-stage PCa, $>90 \%$ of patients initially respond to therapeutic use of androgen deprivation; however, many cases become refractory and progress to androgen-independent PCa (Nelson et al, 2008). Hormonerefractory $\mathrm{PCa}$ is currently difficult to treat and most clinical trials for advanced PCa have shown limited benefits, with disease progression and metastasis to bone or other sites (Bott et al, 2003; Timsit et al, 2008). Thus, new prognostic markers and effective treatment strategies are urgently needed.

MicroRNAs, small non-coding RNAs 20-22 nucleotides in length, are involved in crucial biological processes, including development, differentiation, apoptosis, and proliferation (Bartel, 2004). They pair imperfectly with target mRNAs of protein-coding genes and thereby regulate transcriptional or post-transcriptional expression (Bartel, 2009). Bioinformatic predictions indicate that

\footnotetext{
*Correspondence: Dr N Seki; E-mail: naoseki@faculty.chiba-u.jp

${ }^{5}$ These authors contributed equally to this work

Received I3 May 2011; revised 3 October 201 I; accepted 10 October 20 I ; published online 8 November $201 \mathrm{I}$
}

miRNAs regulate $>30 \%$ of the protein-coding genes (Filipowicz et al, 2008). It is estimated that $\sim 1000$ miRNAs exist in the vertebrate genome. At present, 1424 human miRNAs have been registered at miRBase release 17.0 (http://microrna.sanger.ac.uk/). A growing body of evidence indicates that miRNAs contribute to the initiation and development of many types of human cancer (Zhang et al, 2007). Overexpressed miRNAs could act as oncogenes by repressing tumour suppressor genes. Analogously, miRNAs which normally suppress oncogenes could permit their function when underexpressed (Davis and Hata, 2010).

Many genome-wide profiling studies have been carried out to identify differentially expressed miRNAs (Lu et al, 2005; Calin and Croce, 2006). In comparative miRNA expression studies, several miRNAs (e.g., the $m i R-34$ family, the $m i R-200$ family, $m i R-101$, $m i R-15 a / 16, m i R-205, m i R-146$, and $m i R-145)$ were often found to be downregulated. Those observations suggested that these miRNAs could be important in PCa initiation and development (Catto et al, 2011). Functional analyses of these miRNAs have been conducted at many research facilities. Furthermore, miRNA profile in PCa provides evidence that miRNAs can be used as diagnostic and prognostic markers (Schaefer et al, 2010). More recently, we and other researchers demonstrated that restoration of miR-145 inhibited cell proliferation, migration, and invasion in PCa cells 
(Zaman et al, 2010; Fuse et al, 2011). We performed genome-wide gene expression analysis to identify candidate genes targeted by $m i R-145$, and several oncogenic genes were identified, such as FSCN1 and SWAP70 (Chiyomaru et al, 2011; Fuse et al, 2011). The identification of tumour suppressive miRNAs and their target genes could provide new insights into potential mechanisms of PCa oncogenesis.

Recently, our miRNA expression signature analyses showed that $m i R-1$ and $m i R-133 a$ were significantly reduced in several types of cancer (Kano et al, 2010; Yoshino et al, 2011; Nohata et al, 2011a). Furthermore, overexpression of both miRNAs inhibited cancer cell proliferation and induced cancer cell apoptosis (Nasser et al, 2008; Chiyomaru et al, 2010b; Kawakami et al, 2011; Yoshino et al, 2011; Nohata et al, 2011b). Interestingly, miR-1-1/miR-133a-2 and $m i R$ $1-2 / m i R-133 a-1$ are clustered on different chromosomal regions in the human genome, $20 \mathrm{q} 13.33$ and $18 \mathrm{q} 11.2$, respectively. It is well known that several miRNAs form a cluster in the human genome such as $m i R-17-92, m i R-106 a-368, m i R-221-222, m i R-106 b-25$ and the $m i R-200$ family. In PCa oncogenesis, the $m i R-15 a / 16-1$ cluster acts as a tumour suppressor by targeting multiple oncogenes, including BCL2, CCND1, and WINT3A (Bonci et al, 2008).

We hypothesised that $m i R-1$ and $m i R-133 a$ might be previously unidentified tumour suppressive miRNAs in PCa. The next challenge was to identify miR-1- and miR-133a-regulated cancer pathways. For target genes searches of $m i R-1$ and $m i R-133 a$ in PCa cells, we performed genome-wide gene expression analyses. We focused on the purine nucleoside phosphorylase (PNP) gene as a candidate target of $m i R-1$ and $m i R-133 a$ in PCa cells. Insights into the association between tumour suppressive miRNAs and their target oncogene networks could enhance our understanding of the molecular mechanism of PCa oncogenesis.

\section{MATERIALS AND METHODS}

\section{Clinical prostate specimens}

The clinical specimens were obtained from patients in Teikyo University Chiba Medical Center Hospital from 2008 to 2010. All the patients had elevated levels of prostate-specific antigen and had undergone transrectal prostate needle biopsy. Prostatic cancerous tissues (PCa, $n=15$ ) and non-cancerous tissues (non$\mathrm{PCa}, n=17$ ) were used in this study. The patients' characteristics are shown in Table 1 and Supplementary Table 1. Written consent of tissue donation for research purposes was obtained from patients before tissue collection. The protocol was approved by the Institutional Review Board of Teikyo University. To justified tissue composition, a pair of needle biopsy specimen was collected from same region in the patients in this study, and one was subjected to pathological justification; no cancerous tissue was found in specimens of Non-PCa.

\section{Cell culture}

We used two human PCa cell lines, PC3 and DU145, which were obtained from the American Type Culture Collection (Manassas, VA, USA) and were maintained in RPMI-1640 medium supplemented with $10 \%$ fetal bovine serum in a humidified atmosphere of $5 \% \mathrm{CO}_{2}$ and $95 \%$ air at $37^{\circ} \mathrm{C}$.

\section{RNA extraction}

Total RNA including miRNA was extracted using the mirVana miRNA isolation kit (Ambion, Austin, TX, USA) using the manufacturer's protocol. The integrity of the RNA was checked with the RNA 6000 Nano Assay Kit and a 2100 Bioanalyzer (Agilent Technologies, Santa Clara, CA, USA). Normal prostate RNAs were purchased as follows: prostate 1 (Clontech, Mountain View, CA, USA; Human Prostate Total RNA, no. 636550), prostate 2 (FirstChoice Human
Table I Patients characteristics

\begin{tabular}{llc}
\hline Characteristic & Pca $(\mathbf{n}=\mathbf{I 5})$ & Non-Pca $(\boldsymbol{n}=\mathbf{I 7})$ \\
\hline $\begin{array}{l}\text { Age (years) } \\
\text { Median (range) }\end{array}$ & $72(63-88)$ & $63(53-85)$ \\
PSA (ng ml $\left.{ }^{-1}\right)$ & & \\
Median (range) & $153(3.4-2530)$ & \\
T stage & \\
T3a & $6(40 \%)$ & \\
T3b & $4(27 \%)$ & \\
T4 & $5(33 \%)$ \\
N stage & \\
No & $3(20 \%)$ \\
NI & $12(80 \%)$ \\
M stage & \\
M0 & $7(47 \%)$ \\
MI & $8(53 \%)$ \\
Gleason score & \\
$4+3$ & $1(7 \%)$ \\
$4+4$ & $6(40 \%)$ \\
$4+5$ & $7(46 \%)$ \\
$5+5$ & $1(7 \%)$ \\
\hline
\end{tabular}

Abbreviations: $\mathrm{PCa}=$ prostate cancer; PSA $=$ prostate-specific antigen.

Prostate Total RNA, \#AM7988, Applied Biosystems, Foster City, CA, USA), and prostate 3 (Biochain Total RNA-Human adult Normal Tissue, Hayward, CA, USA; no. R1234201-P).

\section{Quantitative real-time RT - PCR}

First-strand cDNA was prepared from total RNA $(1 \mu \mathrm{g})$ using a High Capacity cDNA Reverse Transcription Kit (Applied Biosystems). In the real-time PCR step, complementary DNA was amplified and the gene-specific PCR products were assayed using the 7900-HT Real-Time PCR System according to the manufacturer's protocol. Thermal cycling conditions were as follows: $95^{\circ} \mathrm{C}$ for $10 \mathrm{~min}, 40$ cycles of $95^{\circ} \mathrm{C}$ for $15 \mathrm{~s}$ and $63^{\circ} \mathrm{C}$ for $1 \mathrm{~min}$. TaqMan probes and primers for PNP (assay ID: Hs00165367_m1) and human GAPDH (assay ID: Hs0329097_g1) were obtained from Applied Biosystems (Assay-On-Demand Gene Expression Products). For miRNA RT-PCR, the cDNA strand was synthesised using TaqMan quantitative real-time PCR (TaqMan MicroRNA Assay; Applied Biosystems). The expression levels of $m i R-1$ (assay ID: 002222) and $m i R-133 a$ (assay ID: 002246) were normalised to RNU6B (Assay ID 001973). All reactions were performed in triplicate, and negative controls lacking cDNA were included. The data were analysed with the delta - delta Ct method to calculate the fold change. About the internal controls, we examined the unevenness between the clinical samples and adopted to use $G A P D H$ and RNU6B in this study.

\section{Mature miRNA and siRNA transfection}

Pre-miR and negative-control miRNA (Applied Biosystems) were used in the gain-of-function experiments, whereas PNP siRNA (Cat \# HSS107263 and HSS181558; Invitrogen, Carlsbad, CA, USA) and negative-control siRNA (D-001810-10; Thermo Fisher Scientific, Waltham, MA, USA) were used in the loss-of-function experiments. As previously described (Ichimi et al, 2009), PC3 and DU145 cells were transiently transfected with either precursors of $m i R-1$ and $m i R-133 a$ or negative control using Lipofectamine RNAiMAX transfection reagent (Invitrogen), according to the manufacturer's recommendations. Mock transfections, which only 
had the transfection reagent, were also used as controls. The transfection efficiency of miRNA into cancer cells was evaluated by downregulation of mRNA levels of PTK9 as described previously (Ichimi et al, 2009). Cells were seeded in 6-well plates for the mRNA and protein extraction and the wound-healing assays $\left(25 \times 10^{4}\right.$ per well), in 24-well plates for luciferase reporter assays $\left(10 \times 10^{4}\right.$ per well), and in 96-well plates for XTT assays (3000 per well).

\section{Cell proliferation, migration, and invasion assays}

Cell proliferation was determined by using an XTT assay (Roche Applied Sciences, Tokyo, Japan) performed according to the manufacturer's instructions. Cell migration activity was evaluated with a wound-healing assay. Cells were plated in 6-well dishes, and the cell monolayers were scraped using a P-20 micropipette tip. The initial gap length $(0 \mathrm{~h})$ and the residual gap length $24 \mathrm{~h}$ after wounding were calculated from photomicrographs. A cell invasion assay was carried out using modified Boyden Chambers consisting of transwell-precoated Matrigel membrane filter inserts with $8 \mu \mathrm{m}$ micron pores in 24-well tissue culture plates (BD Biosciences, Bedford, MA, USA). Minimum essential medium containing $10 \%$ fetal bovine serum in the lower chamber served as the chemoattractant, as described previously (Chiyomaru et al, 2010b). All experiments were performed in triplicate.

\section{Western blot analysis}

After 3 days of transfection, protein lysates $(30 \mu \mathrm{g})$ were separated on NuPAGE on $4-12 \%$ bis-tris gels (Invitrogen) and transferred onto a polyvinylidene fluoride membrane. Immunoblotting was done with diluted $(1: 500)$ polyclonal PNP antibody (HPA001625; Sigma-Aldrich, St Louis, MO, USA) and GAPDH antibody (MAB374; Chemicon, Temecula, CA, USA). The membrane was washed and then incubated with goat anti-rabbit IgG $(\mathrm{H}+\mathrm{L})$-HRP conjugate (BIO-RAD, Hercules, CA, USA). Specific complexes were visualised with an echochemiluminescence (ECL) detection system (GE Healthcare, Little Chalfont, UK).

\section{Prediction of miRNA targets}

Oligo-microarray human $44 \mathrm{~K}$ (Agilent) was used for expression profiling of $m i R-1$ - and $m i R-133 a$-transfected $\mathrm{PCa}$ cell lines (PC3 and DU145) in comparison with miR-negative control transfectants as previously described (Sugimoto et al, 2009). In brief, hybridisation and washing steps were performed in accordance with the manufacturer's instructions. The arrays were scanned using a Packard GSI Lumonics ScanArray 4000 (PerkinElmer, Boston, MA, USA). The data obtained were analysed with DNASIS array software (Hitachi Software Engineering, Tokyo, Japan), which converted the signal intensity for each spot into the text format. The $\log 2$ ratios of the median subtracted background intensity were analysed. Data from each microarray study were subjected to global normalisation.

The predicted target genes and their miRNA binding site seed regions were investigated using TargetScan (release 5.1, http://www.targetscan.org/). The sequences of the predicted mature miRNAs were confirmed by referring to miRBase (release 17.0; http://microrna.sanger.ac.uk/).

\section{Plasmid construction and dual-luciferase reporter assays}

$m i R-1$ and $m i R-133 a$ target sequences were inserted between the XhoI-PmeI restriction sites in the $3^{\prime} \mathrm{UTR}$ of the hRluc gene in the psiCHECK-2 vector (C8021; Promega, Madison, WI, USA). Full-length $3^{\prime}$ UTR sequences of PNP mRNA and specific miRNA target sequences (Supplementary Table 1) for $m i R-1$ and $m i R-133 a$ were artificially synthesised and inserted into the vector. In addition, we constructed three mutant vectors in which the specific sites targeted by the miRNAs were deleted. Following that, PC3 cells were transfected with $5 \mathrm{ng}$ of vector, $10 \mathrm{nM}$ of miRNA, and $1 \mu \mathrm{l}$ of Lipofectamine 2000 (Invitrogen) in $100 \mu \mathrm{l}$ of Opti-MEM (Invitrogen). The activities of firefly and Renilla luciferases in cell lysates were determined with a dual-luciferase assay system (E1910; Promega). Normalised data were calculated as the quotient of Renilla/firefly luciferase activities.

\section{Immunohistochemistry}

A tissue microarray containing $60 \mathrm{PCa}$ specimens, 10 prostatic intraepithelial neoplasias (PINs), and 10 prostatic hyperplastic samples was obtained from Provitro (Berlin, Germany) (Cat \#401 2209, Lot \#146P260710.1-11, Berlin, BRD). Detailed information on all tumour specimens can be found at http://www.provitro.co.uk/ Neoplastic-tumour-TMA.82.0.htmL. Immunostaining was done on the tissue microarray following the manufacturer's protocol. The primary rabbit polyclonal antibodies against PNP (Sigma-Aldrich) were diluted $1: 450$. The slides were treated with biotinylated goat anti-rabbit IgG $(\mathrm{H}+\mathrm{L})$ (Vector Laboratories, Burlingame, CA, USA). Diaminobenzidine-hydrogen peroxide (Sigma-Aldrich) was the chromogen and the counterstaining was done with $0.5 \%$ haematoxylin. Immunostaining was evaluated according to the scoring method as described previously (Zhang et al, 2010). Each case was scored on the basis of the intensity and area of staining. The intensity of staining was graded on the following scale: 0 , no staining; $1+$, mild staining; $2+$, moderate staining; and $3+$, intense staining. The area of staining was evaluated as follows: 0 , no staining of cells in any microscopic field; $1+,<30 \%$ of cells stained positive; $2+, 30-60 \%$ stained positive; and $3+,>60 \%$ stained positive. The immunostaining scores (intensity + extent) were combined and analysed.

\section{Statistical analysis}

The relationship between two variables and the numerical values obtained by real-time RT-PCR were analysed using the MannWhitney $U$-test. The relationship among three variables and the numerical values were analysed using the Bonferroni-adjusted Mann - Whitney $U$-test. Expert StatView analysis software (version 4; SAS Institute Inc., Cary, NC, USA) was used in both cases. In the comparison among three variables, a non-adjusted statistical level of significance of $P<0.05$ corresponds to a Bonferroni-adjusted level of $P<0.0167$.

\section{RESULTS}

\section{Repressed expression of $m i R-1$ and $m i R-133 a$ in PCa specimens}

We evaluated expression levels of $m i R-1$ and $m i R-133 a$ in PCa $(n=15)$ and non-PCa $(n=17)$ tissues. Patient characteristics are shown in Table 1 and Supplementary Table 1. RNA was extracted and miRNA expression levels of $m i R-1$ and $m i R-133 a$ were determined by RT-PCR. The expression levels of $m i R-1$ and miR-133a were significantly lower in PCa compared with non-PCa tissues $(P=0.0001$ and $P=0.0002$, respectively; Figure $1 \mathrm{~A})$. The expression levels of $m i R-1$ and $m i R-133 a$ were analysed for their correlation. A correlation coefficient of 0.571 with $P<0.001$ indicated that $m i R-1$ expression was highly correlated with that of $m i R-133 a$ (Figure 1B).

\section{Effect of $m i R-1$ and $m i R-133 a$ transfection on cell proliferation, migration, and invasive activity in PCa cell lines}

We evaluated the transfection efficiency of the miRNAs in cancer cell lines based on the downregulation of mRNA expression levels 

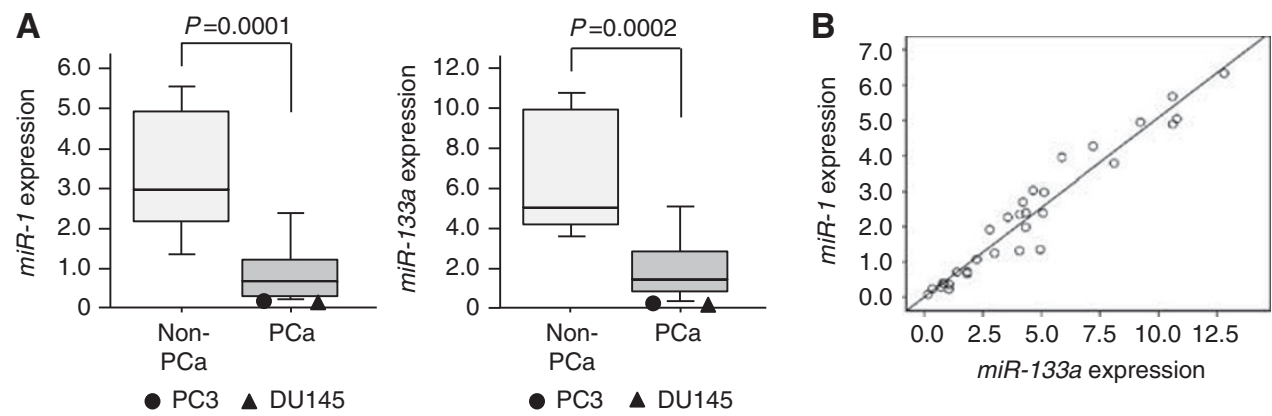

Figure I (A) The expression levels of miR-I and miR-/33a. Real-time RT-PCR showed that the expression levels of both miRNAs were significantly lower in PCa clinical specimens than in Non-PCa specimens. Expression levels of miR-I and miR- / 33a in two PCa cell lines were plotted with circles as PC3 and triangles as DUI45, respectively. miR-I and miR-I33a expression levels were significantly lower in PC3 and DUI45 cells than in non-PCa tissues. (B) The correlated expression of miR-I and miR-I33a. The correlation coefficient of $0.57 \mid$ with $P<0.001$ indicates that miR-I expression was highly correlated with that of miR-133a.

A

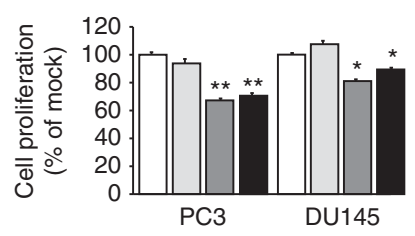

$\square$ Mock
B

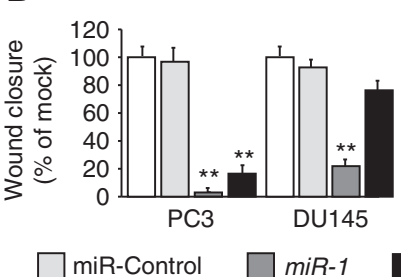

C

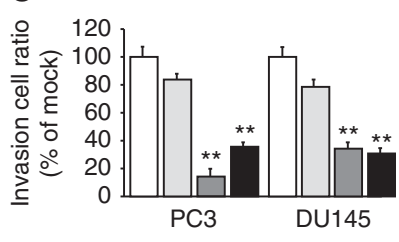

$\operatorname{miR}-133 a$

Figure 2 Effects of miR-I and miR-I 33 a transfection on PC3 and DUI 45 cells. (A) Suppression of PC3 and DUI45 cell proliferation after transfection with either miRNA as determined by XTT assay. (B) Suppression of PC 3 and DUI 45 cell migration activity after miRNA transfection as determined by the wound-healing assay. (C) Suppression of PC3 and DUI45 cell invasion activity after transfection with miRNAs as determined with the Matrigel invasion assay. ${ }^{*} * P<0.0001 ; * P<0.0005$.

of protein tyrosine kinase 9 (PTK9, alias as twinfilin: TWF1) after $m i R-1$ transfection. As a result of our microarray analysis of $m i R-1$ transfectants, it was admitted that PTK9 expression was downregulated (Supplementary Table 2A). This thing shows that transfection of miRNAs was effectiveness in cancer cells.

The expression levels of $m i R-1$ and $m i R-133 a$ in PC3 and DU145 were determined by RT-PCR and compared with clinical specimens. The expression levels of $m i R-1$ and $m i R-133 a$ were significantly lower in PC3 and DU145 than those seen in tissues (Figure 1A).

To examine the functional roles of $m i R-1$ and $m i R-133 a$, we performed gain-of-function studies using miRNA transfections into PC3 and DU145 cells. The XTT assay revealed cell proliferation inhibition in the two miRNA-transfected $\mathrm{PCa}$ cell lines in comparison with mock and the control transfectants (Figure 2A).

The wound-healing assay demonstrated significant cell migration inhibitions in these miRNA-transfected PC3 cell lines compared with their counterparts (Figure 2B). However, no significant inhibition was observed in miR-133a-transfected DU145 cell lines (Figure 2B). Supplementary Figure 2A shows the actual images of the wound-healing assay.

The Matrigel invasion assay demonstrated that the number of invading cells was significantly decreased in these miRNA transfectants compared with their counterparts (Figure 2C). Supplementary Figure $2 \mathrm{~B}$ shows the actual images of the invasion assay.

It is plausible the $m i R-1 / m i R-133 a$ cluster may have important role as tumour suppressors through downregulating these oncogenic genes. However, we found no simultaneous effect of cell viability inhibition by $m i R-1$ and $m i R-133 a$ co-transfection (Supplementary Figure 1).

\section{Identification of $m i R-1$ and $m i R-133 a$ target genes by genome-wide gene expression analysis}

To identify the target genes of $m i R-1$ and $m i R-133 a$, we performed genome-wide gene expression analysis with $m i R-1, m i R-133 a$, and negative-control miRNA transfections into PC3 and DU145 cells. Downregulated genes in either $m i R-1$ or $m i R-133 a$ transfectants with less than a -1.0 ( $\log 2$ ratio) downregulation compared with the control transfectants are shown in Supplementary Table 2A and $\mathrm{B}$.

According to the microarray data, a total of 14 genes were downregulated by both $m i R-1$ and $m i R-133 a$ transfections (Table 2). The Target Scan Program showed that six genes had putative target sites of both $m i R-1$ and $m i R-133 a$ in their $3^{\prime}$ UTR (TAGLN2: transgelin 2, WDR78: WD repeat domain 78, C4orf34: chromosome 4 open reading frame 34, PNP: purine nucleoside phosphorylase, LASS2: LAG1 homologue, ceramide synthase 2 and STXBP4: syntaxin binding protein 4; Table 2). To confirm the expression levels of these genes in the clinical specimens ( $\mathrm{PCa}$ and non-PCa tissues), RT - PCR was performed. The data showed that $P N P$ was highly expressed in the PCa specimens compared with non-PCa tissues (Supplementary Figure 4). These results indicated that $P N P$ was a possible target gene of $m i R-1$ and $m i R-133 a$ and function as an oncogene. The current microarray data were approved by the Gene Expression Omnibus (GEO) and were assigned GEO accession number GSE26032.

\section{$P N P$ as a target of post-transcriptional repression by $m i R-1$ and $m i R-133 a$}

The mRNA and protein expression levels of PNP were markedly downregulated in $m i R-1$ - and miR-133a-transfected PC3 and 
Table 2 Downregulated genes in miR-I and miR-/33a transfectants

\begin{tabular}{|c|c|c|c|c|c|c|c|c|}
\hline \multirow[b]{3}{*}{ Entrez Gene ID } & \multirow[b]{3}{*}{ Symbol } & \multicolumn{5}{|c|}{ Fold change (log2 ratio) } & & \\
\hline & & \multicolumn{2}{|c|}{ PC3 } & \multicolumn{2}{|c|}{ DUI45 } & \multirow[b]{2}{*}{ Average } & \multicolumn{2}{|c|}{ Target sites } \\
\hline & & miR-I & miR-I33a & miR-I & miR-I33a & & miR-I & miR-I33a \\
\hline 8407 & TAGLN2 & -3.40 & -2.60 & -1.56 & $-|.7|$ & -2.32 & + & + \\
\hline 51776 & ZAK & -1.77 & -2.97 & -1.38 & -2.33 & -2.11 & - & - \\
\hline 79819 & WDR78 & -1.63 & -2.91 & -1.22 & -1.81 & -1.89 & + & + \\
\hline 83990 & BRIPI & -2.95 & -1.86 & -1.04 & -1.68 & -1.88 & - & - \\
\hline 5819 & PVRL2 & -2.80 & -1.57 & -1.78 & -1.06 & -1.80 & + & - \\
\hline 201895 & C4orf34 & -2.33 & -2.28 & -1.17 & -1.38 & -1.79 & + & + \\
\hline 4860 & PNP & -2.14 & -1.31 & -2.08 & -1.54 & -1.77 & + & + \\
\hline 29956 & LASS2 & -1.15 & -2.45 & -1.12 & -1.48 & -1.55 & + & + \\
\hline 79026 & AHNAK & -1.33 & -2.15 & -1.23 & -1.23 & -1.48 & - & - \\
\hline 4323 & MMPI4 & -1.21 & -1.01 & -1.52 & -1.54 & -1.32 & - & + \\
\hline 53340 & SPAI7 & -1.43 & -1.00 & -1.42 & -1.11 & -1.24 & - & - \\
\hline 252983 & STXBP4 & -1.03 & -1.40 & -1.09 & -1.35 & -1.22 & + & + \\
\hline 56267 & CCBL2 & -1.14 & -1.22 & -1.14 & -1.02 & -1.13 & - & + \\
\hline | 46779 & EFCAB3 & -1.10 & -1.08 & -1.16 & -1.17 & -1.13 & - & - \\
\hline
\end{tabular}

A

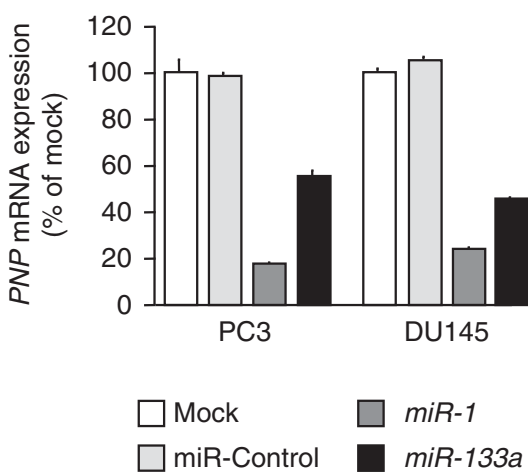

B

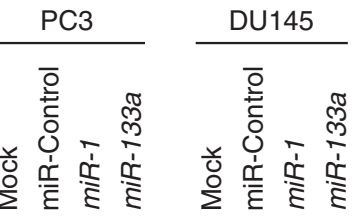

PNP

GAPDH
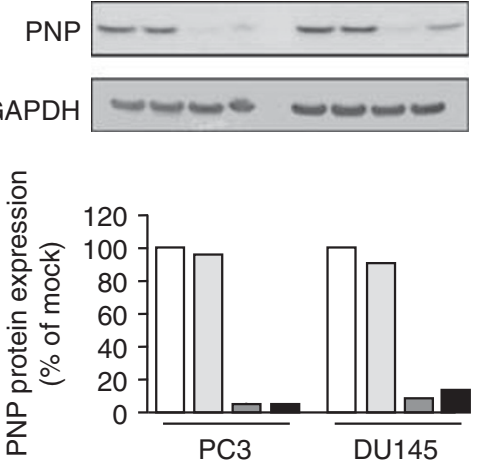

Figure 3 PNP expression was suppressed by miR-I and miR- I 33 a transfection at both the mRNA and protein levels in PCa cell lines, PC3 and DUI45. (A) PNP mRNA expression after $72 \mathrm{~h}$ transfection with miR-I and miR-133a. GAPDH expression was used for normalisation. (B) PNP protein expression after $72 \mathrm{~h}$ transfection of miRNAs. GAPDH was used as a loading control. The expression ratio of PNP/GAPDH was evaluated using Imagej software (ver. I.43; http://rsbweb.nih.gov/ij/index.htmL).

DU145 cells in comparison with the mock and control transfectants (Figure $3 \mathrm{~A}$ and $\mathrm{B}$ ). We performed a luciferase reporter assay to determine whether PNP mRNA had a functional target site for $m i R-1$ and $m i R-133 a$. We used a vector encoding the $3^{\prime}$ UTR of $P N P$ mRNA including target sites for $m i R-1$ and $m i R-133 a$ (positions $365-371$ and 407-413, respectively; Supplementary Table 3) and found that the luminescence intensity was significantly reduced by transfectants of vector contained wild-type sequence in vector (Figure 4). The luminescence intensity significantly decreased in the presence of either sites targeted by $m i R-1$ or $m i R-133 a$, while the luminescence intensity was not decreased when the seed sequence of both target sites was deleted from the vectors (Figure 4; Supplementary Table 3 ). These data suggest that $m i R-1$ and miR-133a directly bind to specific sites on $3^{\prime} \mathrm{UTR}$ of PNP mRNA.

Effect of PNP knockdown on cell proliferation, migration, and invasion activity in PCa cell lines

The expression levels of PNP mRNA were upregulated in PC3 and DU145 cells compared with non-PCa tissues (Supplementary
Figure 5). There was no inverse correlation between the mRNA expression of $m i R-1 / m i R-133 a$ and $P N P$ in clinical specimens in this study.

To examine the functional role of PNP, we performed loss-offunction studies using two different si-PNP transfections into PC3 and DU145 cells. Expression of both PNP mRNA and PNP protein was markedly repressed in $s i-P N P$ transfectants (Figure $5 \mathrm{~A}$ and $\mathrm{B}$ ).

The XTT assay revealed cell proliferation inhibition in the two si-PNP-transfected PC3 cell lines in comparison with those of the mock and the si-control transfectants $(P<0.0001$; Figure $6 \mathrm{~A})$. However, no significant inhibition was observed in DU145 cell lines (Figure 6A).

The wound-healing assay demonstrated significant cell migration inhibitions in the two si-PNP transfectants compared with their counterparts (Figure 6B). Supplementary Figure 3A shows the actual images of the wound-healing assay.

The Matrigel invasion assay demonstrated that the number of invading cells was significantly decreased in the two si-PNP transfectants compared with their counterparts (Figure 6C). Supplementary Figure 3B shows the actual images of the invasion assay. 


\begin{tabular}{|c|c|c|c|}
\hline 100 & 200 & 300 & 400 \\
\hline
\end{tabular}

\begin{tabular}{|c|c|}
\hline Position $365-371$ of $3^{\prime} U T R$ & Position $407-413$ of $3^{\prime}$ UTR \\
\hline $\begin{array}{l}5^{\prime} \ldots \text { GCUCUUUGGAGAUAAUACAUUCCG . . 3' } \\
3^{\prime} \ldots \text { UAUGUAUGAAGAAAUGUAAGGU . . 5' miR-1 }\end{array}$ & $\begin{array}{l}5^{\prime} \ldots \text { AUCUAAAUCACCAGAGACCAAAC . . 3' } \\
3^{\prime} \ldots \text { AUCGACCAACUUCCCCUGGUUU . . 5' miR-133a }\end{array}$ \\
\hline $\begin{array}{l}5^{\prime} \ldots \text { GCUCUUUGAGAUAAU------G. . 3' } \\
3^{\prime} \ldots \text { UAUGUAUGAAGAAAUGUAAGGU . . 5' miR-1 }\end{array}$ & $\begin{array}{l}5^{\prime} \ldots \text { AUCUAAAUCACCAGA------C. . 3' } \\
3^{\prime} \ldots \text { AUCGACCAACUUCCCCUGGUUU . . 5' miR-133a }\end{array}$ \\
\hline
\end{tabular}

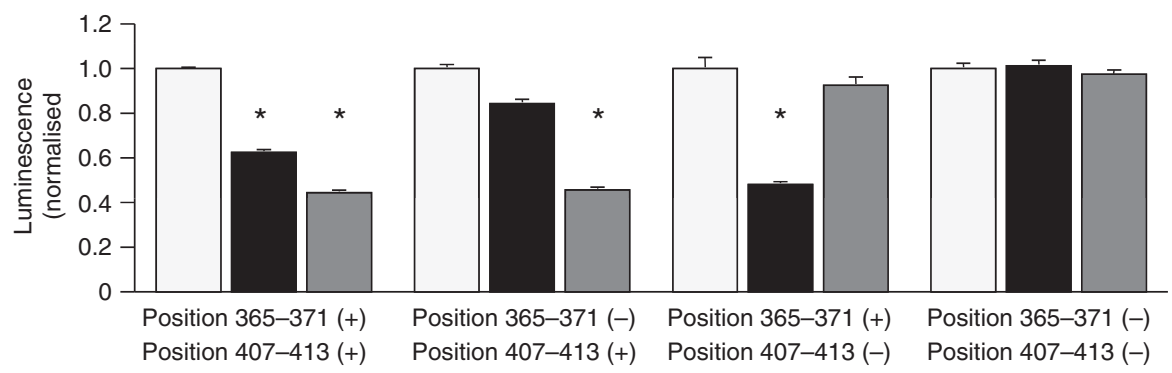

Figure 4 miR- I and miR- $133 a$ binding sites in $3^{\prime} \cup T R$ of PNP mRNA. Luciferase reporter assay using the four types of vector encoding the putative miR- 1 and miR-I 33a target sites; Position 365-37I (+):Position 407-4I3 (+), deletion of putative miR-I target site; Position 365-37I (-):Position 407-4I3 $(+)$, deletion of putative miR-I 33 a target site; Position 365-37I (+):Position 407-4I $3(-)$, deletion of putative target sites of both miR-I and miR-I 33 a; Position 365-37I (-):Position 407-4I3 (-). The Renilla luciferase values were normalised to firefly luciferase values. $* P<0.01$.

A

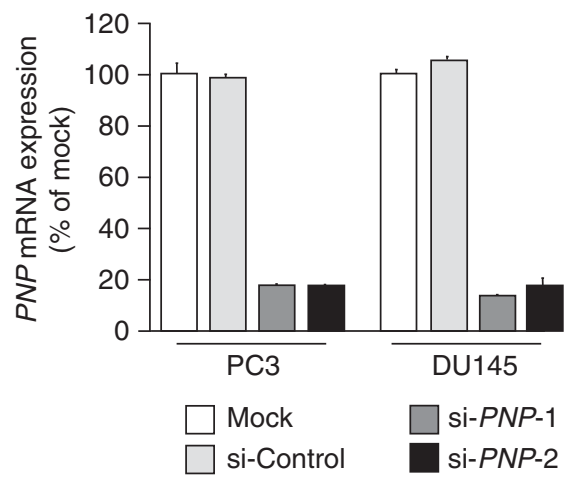

B

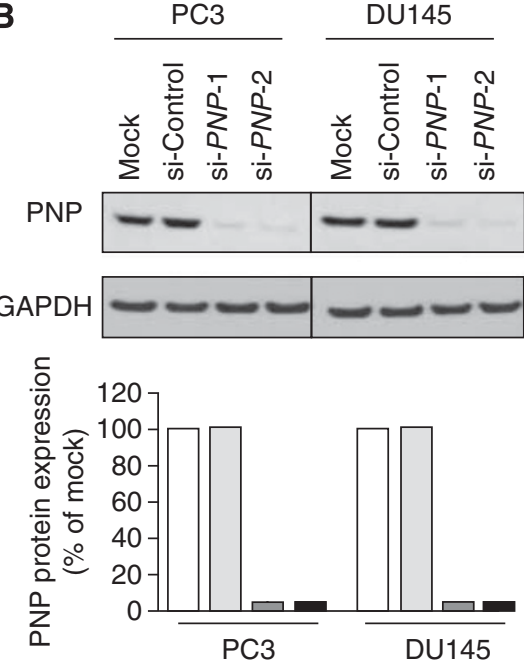

Figure 5 PNP expression was suppressed by si-PNP-I and si-PNP-2 transfection at both the mRNA and protein levels in PCa cell lines, PC3 and DUI 45. (A) PNP mRNA expression $72 \mathrm{~h}$ after transfection of the si-RNAs. GAPDH expression was used for normalisation. (B) PNP protein expression $72 \mathrm{~h}$ after transfection of the si-RNAs. GAPDH was used as a loading control. The expression ratio of PNP/GAPDH was evaluated using ImageJ software (ver. I.43; http://rsbweb.nih.gov/ij/index.htmL).

\section{Immunohistochemistry of PNP in tissue microarray}

Purine nucleoside phosphorylase was detected by immunohistochemical staining. We compared the expression levels in $\mathrm{PCa}$, intraepithelial neoplasm (PIN) and normal prostatic tissue. The PNP was strongly expressed in several tumour lesions (Gleason Score 3+4, pT3aN0; Figure 7A) and PIN lesions (Figure 7B), whereas no or low expression was observed in the normal tissues (Figure 7C). The expression score of PCa was significantly higher than that of normal tissues $(P=0.0037$; Figure 7$)$. There was no significant difference of expression of PNP analysed with clinicopathological parameters.

\section{DISCUSSION}

Innumerable articles have reported that miRNAs are aberrantly expressed in many types of human cancers. miRNA expression profiles of $\mathrm{PCa}$ also have been reported by many researchers (Porkka et al, 2007; Ozen et al, 2008; Gandellini et al, 2009; 
A

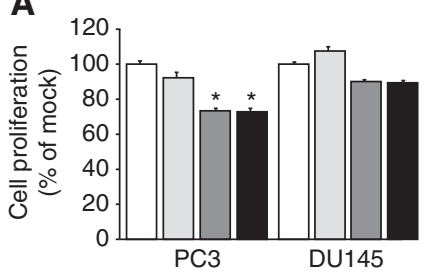

B

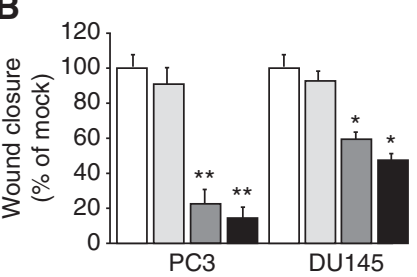

C

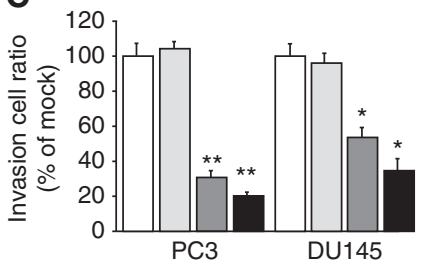

$\square$ Mock $\square$ si-Control $\square$ si-PNP-1 $\square$ si-PNP-2

Figure 6 Effects of PNP knockdown by si-PNP transfection on PCa cell lines, PC3 and DUI45. (A) Cell proliferation determined by the XTT assay; (B) cell migration activity determined by the wound-healing assay; and $(\mathbf{C})$ cell invasion activity determined by the $M$ atrigel invasion assay. $* * P<0.000$ I. $* P<0.01$
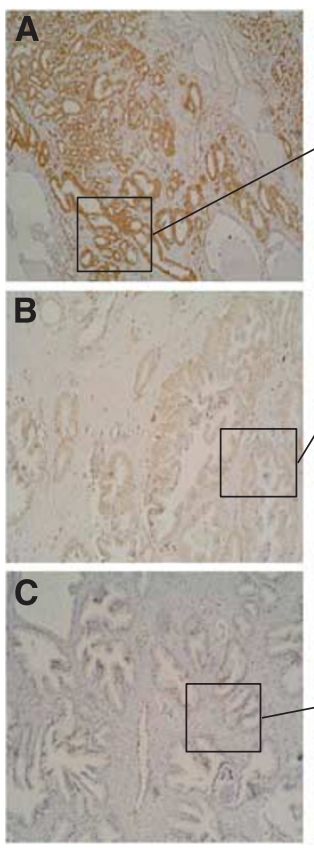

$\times 100$
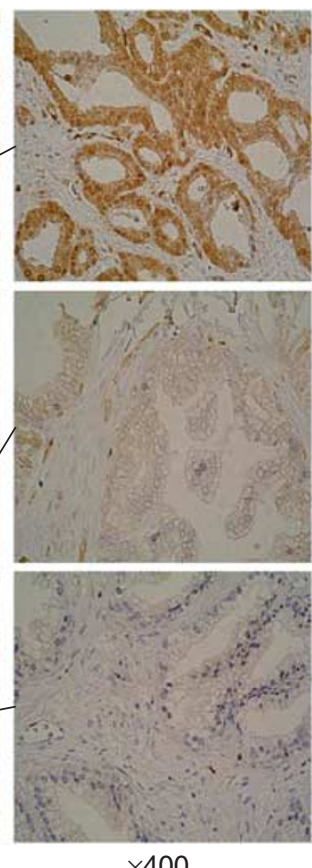

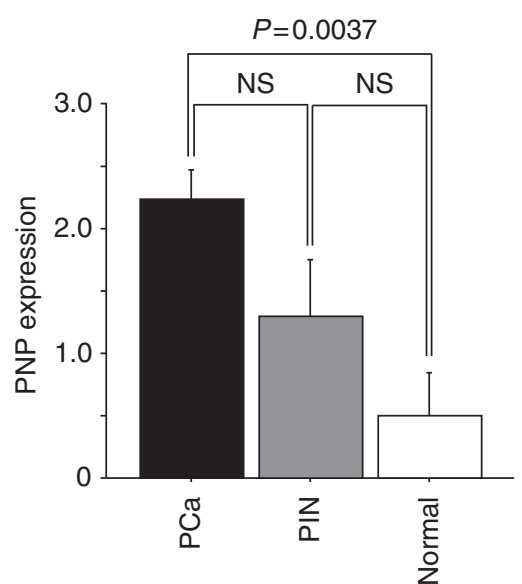

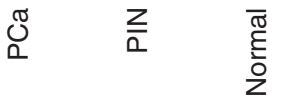

Figure 7 Immunohistochemical staining of PNP in PCa $(n=60)$, PIN $(n=10)$, and normal prostatic tissue ( $n=10)$ by tissue microarray (left panel, original magnification $\times$ 100; right panel, original magnification $\times 400)$. (A) Strongly stained tumour lesion (Gleason Score $3+4$, pT3N0); (B) weakly stained PIN lesion; and (C) negative staining in hyperplastic tissue without malignancy. Right side of the figure: Quantification of PNP expression. Expression of PNP was upregulated in $P C$ a specimens compared with normal hyperplastic tissue $(P=0.0037)$.

Schaefer et al, 2010). While some controversy remains, it is certain that genome-wide expression analysis contributes to our understanding of miRNA's role as oncogenes and/or tumour suppressors (Nicolas et al, 2011). For example, $m i R-15 a / 16-1$ that are clustered together on chromosome 13q14 are established as tumour suppressive miRNAs in human cancers including PCa (Aqeilan et al, 2010). Downregulation of $m i R-15 a$ and $m i R-16-1$ was frequently found in PCa specimens (Porkka et al, 2011). The restoration of both miRNAs in LNCaP cells showed a dramatic apoptotic effect in vitro and in vivo as they targeted multiple oncogenes such as BCL2, CCND1, and WNT3A (Bonci et al, 2008). Interestingly, $B C L 2$ is overexpressed in the majority of patients with hormone-refractory $\mathrm{PCa}$, and mediates resistance to androgen ablation and chemotherapy (Yoshino et al, 2006). These data strongly suggest that downregulation of $m i R-15 a / 16-1$ cluster and overexpression of BCL2 might contribute to PCa oncogenesis.

Like the $m i R-15 a / 16-1$ cluster, several other miRNAs are located in the same chromosomal region. We recognised that $m i R-1$ and $m i R-133 a$ formed clusters in the human genome (18q11.2 and 20q13.33). Furthermore, our miRNA expression signatures revealed that both $m i R-1$ and $m i R-133 a$ were downregulated in several types of cancer such as head and neck cancer, oesophageal cancer, and bladder cancer (Kano et al, 2010; Nohata et al, 2011a; Yoshino et al, 2011). In this study, we first tested the expression levels of $m i R-1$ and $m i R-133 a$ using needle biopsies of $\mathrm{PCa}(n=15)$ and non-PCa $(n=17)$ tissues. We confirmed reduction of both miRNAs in PCa tissues, and suggested that these changes are key steps in oncogenesis or progression in PCa. Next, we investigated the functional significance of $m i R-1$ and $m i R-133 a$ in PCa cells, PC3 and DU145. Our data revealed that restoration of $m i R-1$ or $m i R-133 a$ expression suppressed cancer cell proliferation, migration, and invasion in PC3 and DU145 cells. Our latest data from head and neck squamous cell carcinoma (SCC) and bladder cancer showed that $m i R-1$ and $m i R-133 a$ had a role of tumour suppressors based upon functional analysis of cancer cells (Nohata et al, 2011b; Yoshino et al, 2011). As for the relationship between human cancer and $m i R-1$, recent articles revealed that $m i R-1$ induced apoptosis through repression of $\mathrm{Mcl}-1$ in lung cancer (Nasser et al, 2008). miR-1 also targets $c$-Met in rhabdomyosarcoma (Yan et al, 2009). With regard to $m i R-133 a$, several reports showed that $m i R-133 a$ was underexpressed in pancreatic ductal adenocarcinoma, colon cancer and tongue SCC (Szafranska et al, 2007; Wong et al, 2008; 
Sarver et al, 2009). In tongue SCC, miR-133a inhibited cell proliferation and induced apoptosis and directly bound to oncogenic PKM2 (Wong et al, 2008). Taken together, miR-1 and miR-133a appear to be important miRNAs, acting as tumour suppressors in several human cancers including PCa.

miRNAs are unique in their ability to regulate many proteincoding genes. The elucidation of new networks of cancer is important for our understanding of oncogenesis. Based on this view, we continue our investigation of tumour suppressive miRNAs and their regulation of oncogenic targets in various cancer cells (Kano et al, 2010; Chiyomaru et al, 2010a, 2011; Fuse et al, 2011; Nohata et al, 2011b; Uchida et al, 2011; Yoshino et al, 2011). In this study, we adopted a method of genome-wide gene expression analysis in PC3 and DU145 cells, using miR-1 or $m i R-133 a$ transfectants to identify targets. Genes regulated by both $m i R-1$ and $m i R-133 a$ were identified by examining expression profiles of $m i R-1$ and $m i R-133 a$ transfectants.

Recently, important articles were published regarding $m i R-1$ and $m i R-133 a$ target genes in rhabdomyosarcoma. The expression levels of $m i R-1$ and $m i R-133 a$ were reduced in cell lines of rhabdomyosarcoma. $m i R-1$ and $m i R-133 a$ regulate myogenesis by controlling distinct aspects of the differentiation process (Rao et al, 2006) and have important roles in the proliferation and differentiation of rhabdomyosarcoma (Rao et al, 2010). To investigate the contribution of two miRNAs in rhabdomyosarcoma cells, the expression signatures of $m i R-1$ and $m i R-133 a$ transfectants were reported (Rao et al, 2010). According to the report, $m i R-1$ exerts a strong promyogenic influence on these poorly differentiated tumour cells. The expression signatures of rhabdomyosarcoma and our current signatures were compared. In all, 23 of $62(37.1 \%)$ and 5 of $24(20.8 \%)$ downregulated genes by $m i R-1$ and $m i R-133 a$ transfectants in rhabdomyosarcoma were recognised in our PCa signatures, respectively. This result indicates that the downregulated genes which are common in two signatures contribute to malignant human cells. In addition, the functional analysis of $m i R-1$ or $m i R$ $133 a$ independently regulated genes is another important theme in cancer research field.

In this study, we focused target genes directly downregulated by both $m i R-1$ and $m i R-133 a$, which contain $m i R-1$ and $m i R-133 a$ binding site on their genome sequences. We investigated the mRNA expression levels of six candidate genes (TAGLN2, WDR78, C4orf34, PNP, LASS2, and STXBP4) using PCa or non-PCa clinical specimens. In this analysis, our criterion for selection was that candidate genes were upregulated in cancer tissues. One gene, $P N P$, was chosen for this standard.

To examine the role of PNP in PCa, we examined its expression by immunohistochemical analysis of tissue microarrays. Our data demonstrated that PNP was highly expressed in PCa while it was scarcely stained in normal prostatic tissues. Importantly, we noted intermediate staining of PIN tissues. Our immunohistochemical analysis indicates an important role of PNP in PCa oncogenesis. The phosphorolytic cleavage of inosine, deoxyinosine, guanosine, and deoxyguanosine to the corresponding base and sugar 1 phosphate was catalysed by PNP. Purine nucleoside phosphorylase-deficiency syndrome exhibits profound impairment in the T-cell component, in which $2^{\prime}$-deoxyguanosine accumulates in plasma and deoxyguanosine triphosphate (dGTP) in lymphocytes, thereby leading to dGTP-directed inhibition of DNA synthesis and cell death (Markert, 1991; Arpaia et al, 2000). Purine nucleoside phosphorylase is considered as a therapeutic target in malignant lymphoproliferative diseases. Forodesine (BCX-1777) is a potent inhibitor of human PNP and which induces apoptosis of chronic lymphocytic leukaemia (CLL) cells (Bantia et al, 2003; Ravandi and Gandhi, 2006). Phase 2 clinical trials, conducted from 2005 until 2009, used Forodesine for the treatment of patients with advanced, Fludarabine-refractory CLL (Al-Kali et al, 2010; Balakrishnan et al, 2010). Purine nucleoside phosphorylase might have functions in oncogenesis and progression of $\mathrm{PCa}$; therefore, PNP inhibition might be a target of a strategy for novel treatment of PCa.

The unique point of miRNA biogenesis is that one miRNA regulates many protein-coding genes. However, the nature of miRNA-protein coding gene networks in human genome is unclear. This is why elucidation of tumour suppressive $m i R-1$ and miR-133a regulate cancer networks is important for understanding human PCa oncogenesis.

\section{CONCLUSIONS}

$m i R-1$ and $m i R-133 a$ are frequently reduced in $\mathrm{PCa}$ clinical specimens. Both miRNAs may function as tumour suppressors regulating $P N P$, an oncogenic gene in PCa. The miR-1 and miR-133a cluster regulates novel cancer pathways and as such could provide new insights into molecular mechanisms of $\mathrm{PCa}$ oncogenesis and progression. Further studies could contribute to the development of new therapeutic strategies for PCa.

\section{ACKNOWLEDGEMENTS}

This study was supported by the Ministry of Education, Science, Sports, and Culture, Grant-in-Aid for Scientific Research (C), 21592187 and for Young Scientists (B) 21791530.

Supplementary Information accompanies the paper on British Journal of Cancer website (http://www.nature.com/bjc)

\section{REFERENCES}

Al-Kali A, Gandhi V, Ayoubi M, Keating M, Ravandi F (2010) Forodesine: review of preclinical and clinical data. Future Oncol 6: 1211-1217

Aqeilan RI, Calin GA, Croce CM (2010) miR-15a and miR-16-1 in cancer: discovery, function and future perspectives. Cell Death Differ 17: 215-220

Arpaia E, Benveniste P, Di Cristofano A, Gu Y, Dalal I, Kelly S, Hershfield M, Pandolfi PP, Roifman CM, Cohen A (2000) Mitochondrial basis for immune deficiency. Evidence from purine nucleoside phosphorylasedeficient mice. J Exp Med 191: 2197-2208

Balakrishnan K, Verma D, O'Brien S, Kilpatrick JM, Chen Y, Tyler BF, Bickel S, Bantia S, Keating MJ, Kantarjian H, Gandhi V, Ravandi F (2010) Phase 2 and pharmacodynamic study of oral forodesine in patients with advanced, fludarabine-treated chronic lymphocytic leukemia. Blood 116: $886-892$

Bantia S, Ananth SL, Parker CD, Horn LL, Upshaw R (2003) Mechanism of inhibition of T-acute lymphoblastic leukemia cells by PNP inhibitor BCX-1777. Int Immunopharmacol 3: 879-887
Bartel DP (2004) MicroRNAs: genomics, biogenesis, mechanism, and function. Cell 116: 281 - 297

Bartel DP (2009) MicroRNAs: target recognition and regulatory functions. Cell 136: $215-233$

Bonci D, Coppola V, Musumeci M, Addario A, Giuffrida R, Memeo L, D'Urso L, Pagliuca A, Biffoni M, Labbaye C, Bartucci M, Muto G, Peschle C, De Maria R (2008) The miR-15a-miR-16-1 cluster controls prostate cancer by targeting multiple oncogenic activities. Nat Med 14: $1271-1277$

Bott SR, Birtle AJ, Taylor CJ, Kirby RS (2003) Prostate cancer management: 2. An update on locally advanced and metastatic disease. Postgrad Med J 79: $643-645$

Calin GA, Croce CM (2006) MicroRNA signatures in human cancers. Nat Rev Cancer 6: 857-866

Catto JW, Alcaraz A, Bjartell AS, De Vere White R, Evans CP, Fussel S, Hamdy FC, Kallioniemi O, Mengual L, Schlomm T, Visakorpi T (2011) 
MicroRNA in prostate, bladder, and kidney cancer: a systematic review. Eur Urol 59: 671-681

Chiyomaru T, Enokida H, Kawakami K, Tatarano S, Uchida Y, Kawahara K, Nishiyama K, Seki N, Nakagawa M (2010a) Functional role of LASP1 in cell viability and its regulation by microRNAs in bladder cancer. Urol Oncol; e-pub ahead of print 14 September 2010

Chiyomaru T, Enokida H, Tatarano S, Kawahara K, Uchida Y, Nishiyama K, Fujimura L, Kikkawa N, Seki N, Nakagawa M (2010b) miR-145 and miR-133a function as tumour suppressors and directly regulate FSCN1 expression in bladder cancer. Br J Cancer 102: 883-891

Chiyomaru T, Tatarano S, Kawakami K, Enokida H, Yoshino H, Nohata N, Fuse M, Seki N, Nakagawa M (2011) SWAP70, actin-binding protein, function as an oncogene targeting tumor-suppressive miR-145 in prostate cancer. Prostate 71: 1559-1567

Cooperberg MR, Broering JM, Carroll PR (2009) Risk assessment for prostate cancer metastasis and mortality at the time of diagnosis. I Natl Cancer Inst 101: 878-887

Davis BN, Hata A (2010) microRNA in cancer: the involvement of aberrant microRNA biogenesis regulatory pathways. Genes Cancer 1: 1100-1114

Filipowicz W, Bhattacharyya SN, Sonenberg N (2008) Mechanisms of post-transcriptional regulation by microRNAs: are the answers in sight? Nat Rev Genet 9: 102-114

Fuse M, Nohata N, Kojima S, Sakamoto S, Chiyomaru T, Kawakami K, Enokida H, Nakagawa M, Naya Y, Ichikawa T, Seki N (2011) Restoration of miR-145 expression suppresses cell proliferation, migration and invasion in prostate cancer by targeting FSCN1. Int J Oncol 38: $1093-1101$

Gandellini P, Folini M, Zaffaroni N (2009) Towards the definition of prostate cancer-related microRNAs: where are we now? Trends Mol Med 15: $381-390$

Ichimi T, Enokida H, Okuno Y, Kunimoto R, Chiyomaru T, Kawamoto K, Kawahara K, Toki K, Kawakami K, Nishiyama K, Tsujimoto G, Nakagawa M, Seki N (2009) Identification of novel microRNA targets based on microRNA signatures in bladder cancer. Int J Cancer 125: 345-352

Kano M, Seki N, Kikkawa N, Fujimura L, Hoshino I, Akutsu Y, Chiyomaru T, Enokida H, Nakagawa M, Matsubara H (2010) miR-145, miR-133a and miR-133b: tumor-suppressive miRNAs target FSCN1 in esophageal squamous cell carcinoma. Int J Cancer 127: 2804-2814

Kawakami K, Enokida H, Chiyomaru T, Tatarano S, Yoshino H, Kagara I, Gotanda T, Tachiwada T, Nishiyama K, Nohata N, Seki N, Nakagawa M (2011) The functional significance of miR-1 and miR-133a in renal cell carcinoma. Eur J Cancer; e-pub ahead of print 9 July 2011

Lu J, Getz G, Miska EA, Alvarez-Saavedra E, Lamb J, Peck D, Sweet-Cordero A, Ebert BL, Mak RH, Ferrando AA, Downing JR, Jacks T, Horvitz HR, Golub TR (2005) MicroRNA expression profiles classify human cancers. Nature 435: 834-838

Markert ML (1991) Purine nucleoside phosphorylase deficiency. Immunodefic Rev 3: $45-81$

Nasser MW, Datta J, Nuovo G, Kutay H, Motiwala T, Majumder S, Wang B, Suster S, Jacob ST, Ghoshal K (2008) Down-regulation of micro-RNA-1 (miR-1) in lung cancer. Suppression of tumorigenic property of lung cancer cells and their sensitization to doxorubicin-induced apoptosis by miR-1. J Biol Chem 283: 33394-33405

Nelson CJ, Lee JS, Gamboa MC, Roth AJ (2008) Cognitive effects of hormone therapy in men with prostate cancer: a review. Cancer 113: $1097-1106$

Nicolas FE, Lopez-Gomollon S, Lopez-Martinez AF, Dalmay T (2011) Silencing human cancer: identification and uses of microRNAs. Recent Pat Anticancer Drug Discov 6: 94-105

Nohata N, Hanazawa T, Kikkawa N, Sakurai D, Fujimura L, Chiyomaru T, Kawakami K, Yoshino H, Enokida H, Nakagawa M, Katayama A, Harabuchi Y, Okamoto Y, Seki N (2011a) Tumour suppressive microRNA-874 regulates novel cancer networks in maxillary sinus squamous cell carcinoma. $\mathrm{Br}$ J Cancer 105: 833-841

Nohata N, Sone $\mathrm{Y}$, Hanazawa T, Fuse M, Kikkawa N, Yoshino $\mathrm{H}$, Chiyomaru T, Kawakami K, Enokida H, Nakagawa M, Shozu M, Okamoto Y, Seki N (2011b) miR-1 as a tumor suppressive microRNA targeting TAGLN2 in head and neck squamous cell carcinoma. Oncotarget 2: $29-42$
Ozen M, Creighton CJ, Ozdemir M, Ittmann M (2008) Widespread deregulation of microRNA expression in human prostate cancer. Oncogene 27: 1788-1793

Porkka KP, Ogg EL, Saramaki OR, Vessella RL, Pukkila H, Lahdesmaki H, van Weerden WM, Wolf M, Kallioniemi OP, Jenster G, Visakorpi T (2011) The miR-15a-miR-16-1 locus is homozygously deleted in a subset of prostate cancers. Genes Chromosomes Cancer 50: 499-509

Porkka KP, Pfeiffer MJ, Waltering KK, Vessella RL, Tammela TL, Visakorpi $\mathrm{T}$ (2007) MicroRNA expression profiling in prostate cancer. Cancer Res 67: $6130-6135$

Rao PK, Kumar RM, Farkhondeh M, Baskerville S, Lodish HF (2006) Myogenic factors that regulate expression of muscle-specific microRNAs. Proc Natl Acad Sci USA 103: 8721-8726

Rao PK, Missiaglia E, Shields L, Hyde G, Yuan B, Shepherd CJ, Shipley J, Lodish HF (2010) Distinct roles for miR-1 and miR-133a in the proliferation and differentiation of rhabdomyosarcoma cells. FASEB $J$ 24: $3427-3437$

Ravandi F, Gandhi V (2006) Novel purine nucleoside analogues for T-cell-lineage acute lymphoblastic leukaemia and lymphoma. Expert Opin Investig Drugs 15: $1601-1613$

Sarver AL, French AJ, Borralho PM, Thayanithy V, Oberg AL, Silverstein KA, Morlan BW, Riska SM, Boardman LA, Cunningham JM, Subramanian S, Wang L, Smyrk TC, Rodrigues CM, Thibodeau SN, Steer CJ (2009) Human colon cancer profiles show differential microRNA expression depending on mismatch repair status and are characteristic of undifferentiated proliferative states. BMC Cancer 9: 401

Schaefer A, Jung M, Mollenkopf HJ, Wagner I, Stephan C, Jentzmik F, Miller K, Lein M, Kristiansen G, Jung K (2010) Diagnostic and prognostic implications of microRNA profiling in prostate carcinoma. Int J Cancer 126: $1166-1176$

Sugimoto T, Seki N, Shimizu S, Kikkawa N, Tsukada J, Shimada H, Sasaki K, Hanazawa T, Okamoto Y, Hata A (2009) The galanin signaling cascade is a candidate pathway regulating oncogenesis in human squamous cell carcinoma. Genes Chromosomes Cancer 48: 132-142

Szafranska AE, Davison TS, John J, Cannon T, Sipos B, Maghnouj A, Labourier E, Hahn SA (2007) MicroRNA expression alterations are linked to tumorigenesis and non-neoplastic processes in pancreatic ductal adenocarcinoma. Oncogene 26: $4442-4452$

Timsit MO, Lebret T, Mejean A (2008) Chemotherapy of hormonorefractory and hormonoresistant metastatic prostate cancer. Prog Urol 18(Suppl 7): S365-S375

Uchida Y, Chiyomaru T, Enokida H, Kawakami K, Tatarano S, Kawahara K, Nishiyama K, Seki N, Nakagawa M (2011) MiR-133a induces apoptosis through direct regulation of GSTP1 in bladder cancer cell lines. Urol Oncol; e-pub ahead of print 9 March 2011

Wong TS, Liu XB, Chung-Wai Ho A, Po-Wing Yuen A, Wai-Man Ng R, Ignace Wei $\mathrm{W}$ (2008) Identification of pyruvate kinase type M2 as potential oncoprotein in squamous cell carcinoma of tongue through microRNA profiling. Int J Cancer 123: $251-257$

Yan D, Dong Xda E, Chen X, Wang L, Lu C, Wang J, Qu J, Tu L (2009) MicroRNA-1/206 targets c-Met and inhibits rhabdomyosarcoma development. J Biol Chem 284: 29596-29604

Yoshino H, Chiyomaru T, Enokida H, Kawakami K, Tatarano S, Nishiyama K, Nohata N, Seki N, Nakagawa M (2011) The tumour-suppressive function of miR-1 and miR-133a targeting TAGLN2 in bladder cancer. Br J Cancer 104: $808-818$

Yoshino T, Shiina H, Urakami S, Kikuno N, Yoneda T, Shigeno K, Igawa M (2006) Bcl-2 expression as a predictive marker of hormone-refractory prostate cancer treated with taxane-based chemotherapy. Clin Cancer Res 12: $6116-6124$

Zaman MS, Chen Y, Deng G, Shahryari V, Suh SO, Saini S, Majid S, Liu J, Khatri G, Tanaka Y, Dahiya R (2010) The functional significance of microRNA-145 in prostate cancer. Br J Cancer 103: 256-264

Zhang B, Pan X, Cobb GP, Anderson TA (2007) microRNAs as oncogenes and tumor suppressors. Dev Biol 302: $1-12$

Zhang Y, Ye Y, Shen D, Jiang K, Zhang H, Sun W, Zhang J, Xu F, Cui Z, Wang S (2010) Identification of transgelin-2 as a biomarker of colorectal cancer by laser capture microdissection and quantitative proteome analysis. Cancer Sci 101: 523-529

This work is published under the standard license to publish agreement. After 12 months the work will become freely available and the license terms will switch to a Creative Commons Attribution-NonCommercial-Share Alike 3.0 Unported License. 